\title{
MORPHOLOGY AND STRUCTURE OF THE SOUTHERN PART OF THE NEW HEBRIDES ISLAND ARC SYSTEM
}

\author{
J. DANIEL \\ Office de la Recherche Scientifique et Technique Outre-Mer, Noumea Cedex, Nouvelle Calédonie
}

(Received May 25, 1978; Revised September 22, 1978)

\begin{abstract}
A morphological study of the Southern part of the New Hebrides island arc system makes it possible to define the different structural units:

1) An accretionary prism with a constant width of approximately $75 \mathrm{~km}$ does exist;

2) The morphology of this prism varies rapidly along the arc and is linked, firstly to the morphology and structure of the upper part of the dipping plate and, secondly to the presence of volcanic island acting as sediment sources;

3) The island arc and its connecting structural features such as troughs at the rear of the arc, are disrupted by transversal discontinuities, the largest of which could be related to fractures of the oceanic crust of the dipping plate.
\end{abstract}

\section{Introduction}

The New Hebrides island arc (Figs. 1 and 2), stretching across roughly 1,500 km of the South-West Pacific, is a part of the Indo-Australian and Pacific plates boundary. As opposed to the majority of the peripacific arcs, the dip, as defined by seismicity, faces east towards the ocean; more precisely, the North Loyalty Plateau (Fig. 2) underthrusts the North Fiji Plateau, the origin and the nature of which still remains a subject of conjecture.

The New Hebrides island aro (Fig. 2) is divided into three belts (MrTCheLL and WARDEN, 1971): "a western belt comprising Espiritu Santo and Malekula, an eastern belt consisting of Maewo and Pentecost and a central chain which includes all the active and most of the recently extinct volcanoes." The activity of this volcanic belt (Santa Cruz, Banks, Aoba, Ambrym, Epi, Erromango, Tanna) is related to the present subduction, the origin of which is traced back to 7-8 my (Dugas et al., 1977). The western and eastern belts were formed previously during Oligocene and Miocene and were probably related to subductions involving possible changes of polarity (CARNEY and MACFARLANE, 1977).

In consequence, the northern and central parts of the arc are morphologically complex, whereas the southern part is far more straight forward. This is apparently due to the sole Pliocene-actual subduction in existence. Furthermore the topography of the oceanic crust which makes up the upper part of the dipping plate is so uneven in the northern and central parts that the depth is less than 2,000 $\mathrm{m}$ at the level of Torres Islands and the trench disappears at the level of Espiritu Santo and Malekula islands. Consequently it was decided to study the southern part of the arc between the islands of Efate and Tanna. The profiles shown (Figs. 3 and 5) were recorded during AUSTRADEC

\footnotetext{
* AUSTRADEC group is an association of CEPM (Comité d'Etudes Pétroliéres Marines), CNEXO (Centre National pour l'Exploitation des Oceans), IFP (Institut Français du Pétrole), and ORSTOM (Office de la Recherche Scientifique et Technique Outre-Mer).
} 


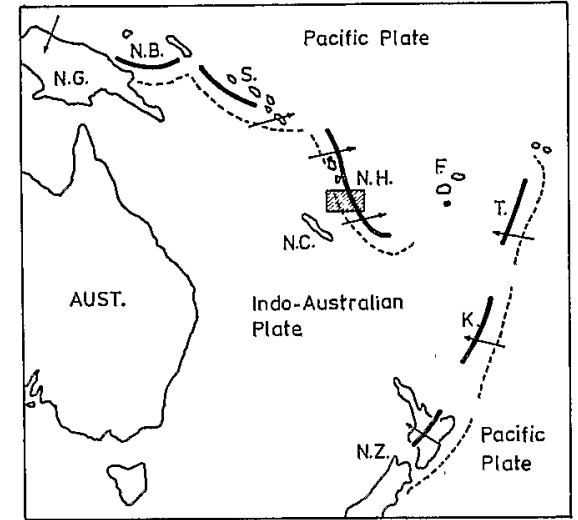

Fig. 1. Subduction zones and island arcs of the South-West Pacific. Dark lines are islands arcs; broken lines are the axis of the trenches. Arrows show underthrusting directions determined from focal mechanisms (from JoHNSON and Molnar, 1972). NG, New Guinea; NB, New Britain; S, Solomon; NH, New Hebrides; NC, New Caledonia; F, Fiji; T, Tonga; K, Kermadec; NZ, New Zealand; AUS, Australia.

(AUSTRADEC group*) and EVA (ORSTOM) cruises of R.V. "Coriolis" and "Le Noroit," R.V. "CHAIN" 800 and 900 (Woodshole Oceanographic Institute), H.M.A.S. "KIMBLA" (ORSTOM and the University New South Wales) and G.C. 30 of R.V. "Glomar Challenger (DSDP)."

The most important morphological features are, firstly, the trench, particularly its inner slope, and secondly the troughs at the rear of the arc.

\section{Morphology of the Trench}

The morphology of the trenches associated with the subduction zones were studied by several authors especially following the conception of the accretionary prism (Dickinson, 1973; Karig, 1974; Karig and Sharman, 1975). The terminology used in this paper is taken from these authors.

The inner wall of a trench can be divided into two sections:

1) The lower slope, between the axis of the trench and the trench slope break;

2) The upper slope, between the trench slope break and the upper slope discontinuity.

The upper slope discontinuity marks the tectonic boundary between the accretionary prism and the frontal arc.

KARIG and ShaRMAN (1975) assumed three principal configurations of the accretionary prism, according to the type of accreted material and its subsequent morphology:

1) The simplest type represented by the Tonga and Mariana island arc systems characterizes the trenches accreting high density and high velocity material;

2) In the second type represented by Sumatra, Java and Luzon, the trench slope break is made up of a sedimentary ridge caused by the sediment feed at the base of the slope;

3) In the third type, represented by Eastern Aleutian, Japan and Middle America arcs, sediments from the frontal arc fill the upper slope and form a broad continental shelf.

According to KARIG and SHARMAN (1975), the inner slope of the New Hebrides island arc system represents the initial stage of the first type of configuration. Nevertheless, Dugas et al. (1977) and RAvENNe et al. (1977), in their general description of the arc, showed that the different morphostructural units were clearly distinguishable, and stressed 


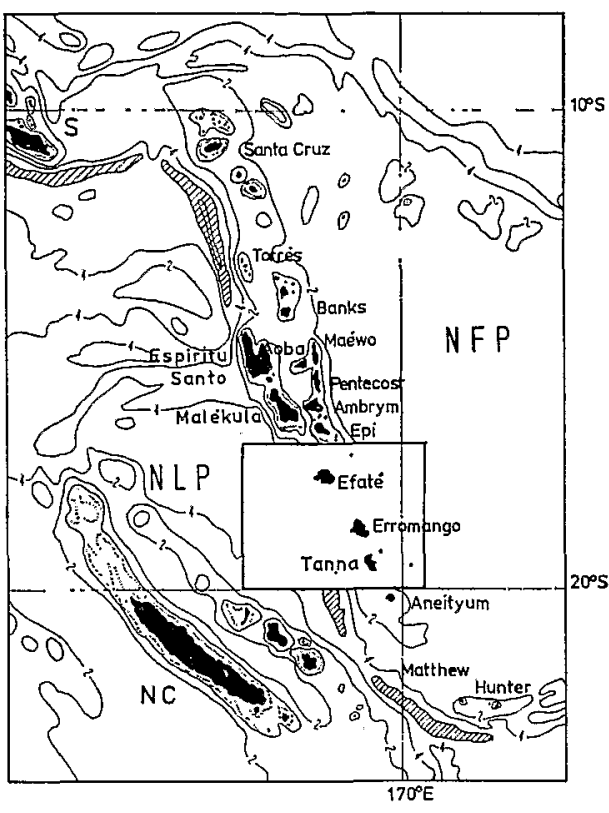

Fig. 2. New Hebrides island arc. Submarine contours are in $\mathrm{km}$. The axis of the trench is shown by hachured area inside of the $6 \mathrm{~km}$ isobath. NC, New Caledonia; S, Solomon; NLP, North Loyalty Plateau; NFP, North Fiji Plateau.

the differences between the northern part, the central part (where the trench disappears) and the southern part. Furthermore, in this southern part, it was shown (DANIEL, 1978) that the morphology of the inner slope varied considerably over short distances.

A bathymetric chart substantiating these variations was drawn up in this southern part (Fig. 3) through several profiles interspaced at 10-15 km.

\subsection{Outer wall of the trench}

The outer wall of the trench is formed by the North Loyalty Plateau. The depth of this plateau is always approximately $4,500 \mathrm{~m}$. However, as can be seen on profile G.C. 30 (Figs. 3 and 4), it appears that a deepening exists in the north which confirms the older age in the north shown by magnetic anomalies (LAPouILLE, 1978).

The outer slope of the trench itself (Fig. 5) has varied configurations: faulted and extremely steep on the CHAIN profile, it becomes more subdued on profile AUS 113, then becomes faulted on profile EVA 201 and finally becomes infinitely more subdued in the south. On the whole, however, the slope is steeper in the northern part of the studied area. The appearance of the slope is qualified both by thickness of the sediments: in the south the thickness is greater and the slope is more subdued, and by the configuration of the basement itself.

\subsection{Trench}

It is clear from the bathymetric chart (Fig. 3) that the curve of the trench axis is slightly arched. It would be necessary to know more precisely the termination of the trench in North-West Efate so as to pinpoint the extend of this curve. . Furthermore, as pointed out on the $5,000 \mathrm{~m}$ isobath the trench tends to widen in the South. 


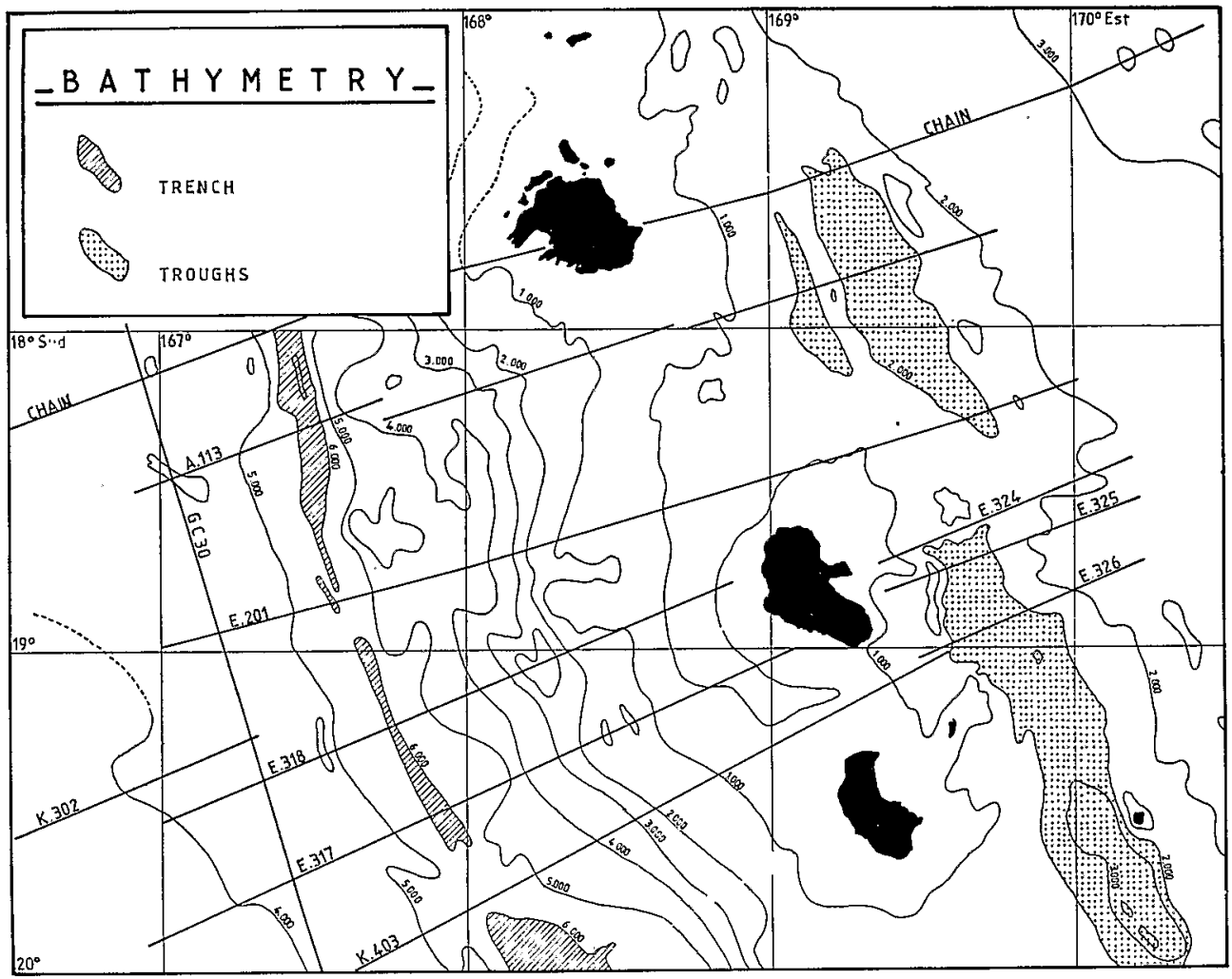

Fig. 3. Bathymetry and localisation of the profiles.

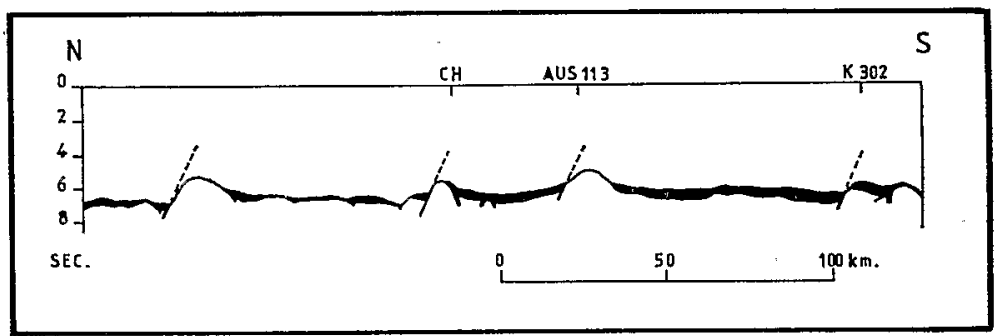

Fig. 4. G.C. 30 (Glomar Challenger) profile on the North Loyalty Plateau.

\subsection{Inner wall of the trench}

From the 6 profiles shown on Fig. 5, it can be seen that the inner slope varies considerably from one profile to another although the width of the accretionary prism (between the axis of the trench and the upper slope discontinuity) remains virtually constant at approximately $75 \mathrm{~km}$. Four types of inner slopes can be determined by grouping them in twos (Fig. 6).

Group A. These refer to the slopes observed in the northern part of the studied area: both flanks of the trench are fairly steep and the configuration of the upper slope differs 


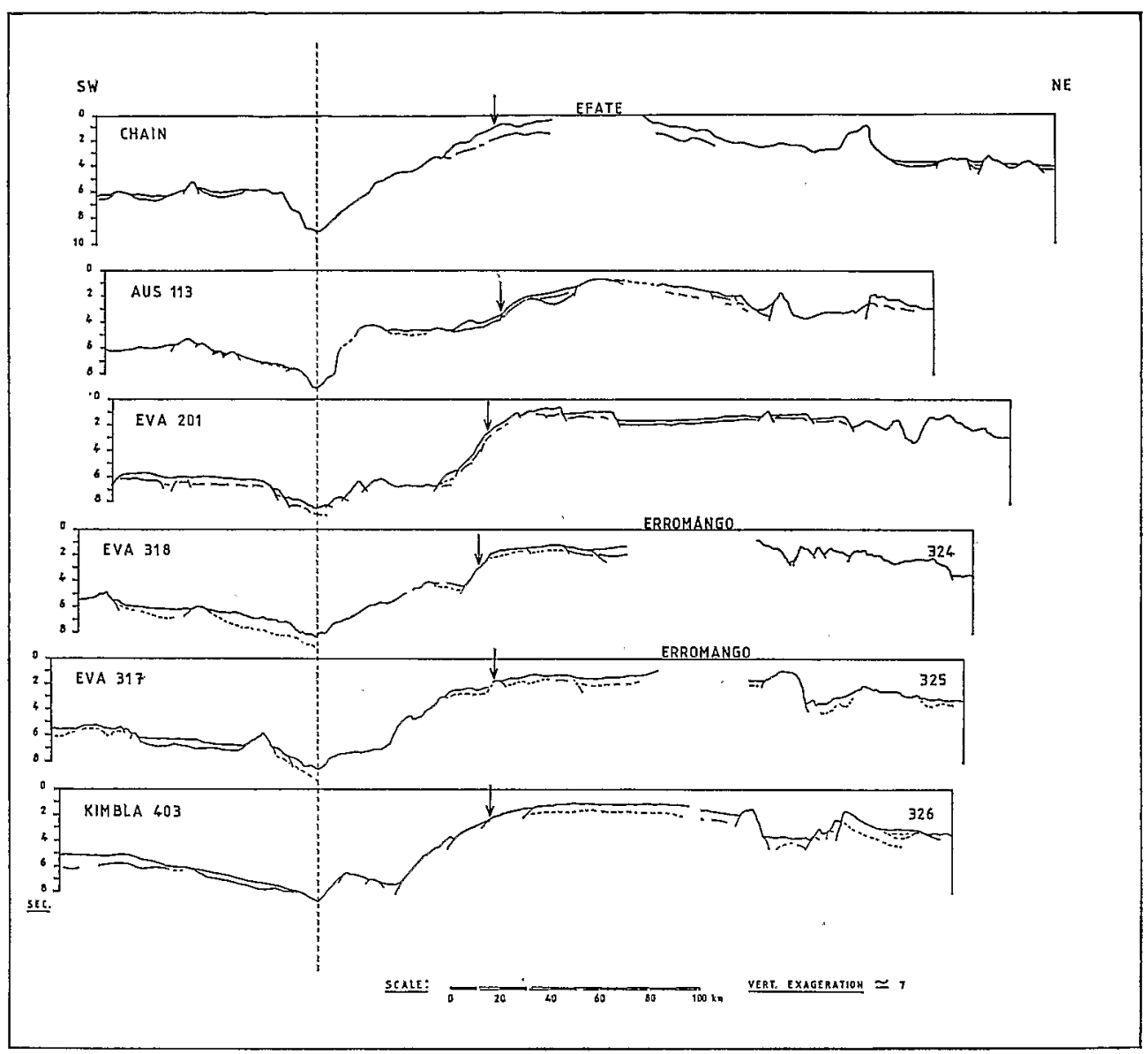

Fig. 5. Bathymetric and seismic reflection profiles across the New Hebrides island arc. Profiles are normalized to the trench axis (broken line). Arrows show the upper slope discontinuity,

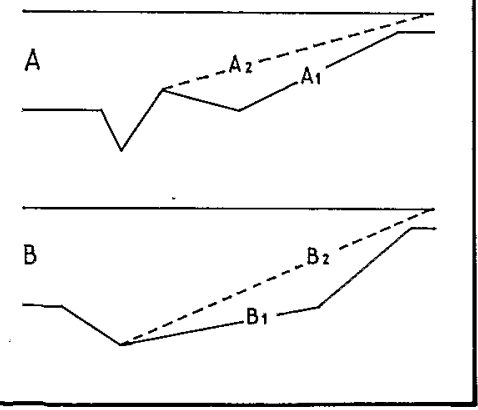

Fig. 6. Sketch of different types of inner slope of the trench observed in the studied area. 


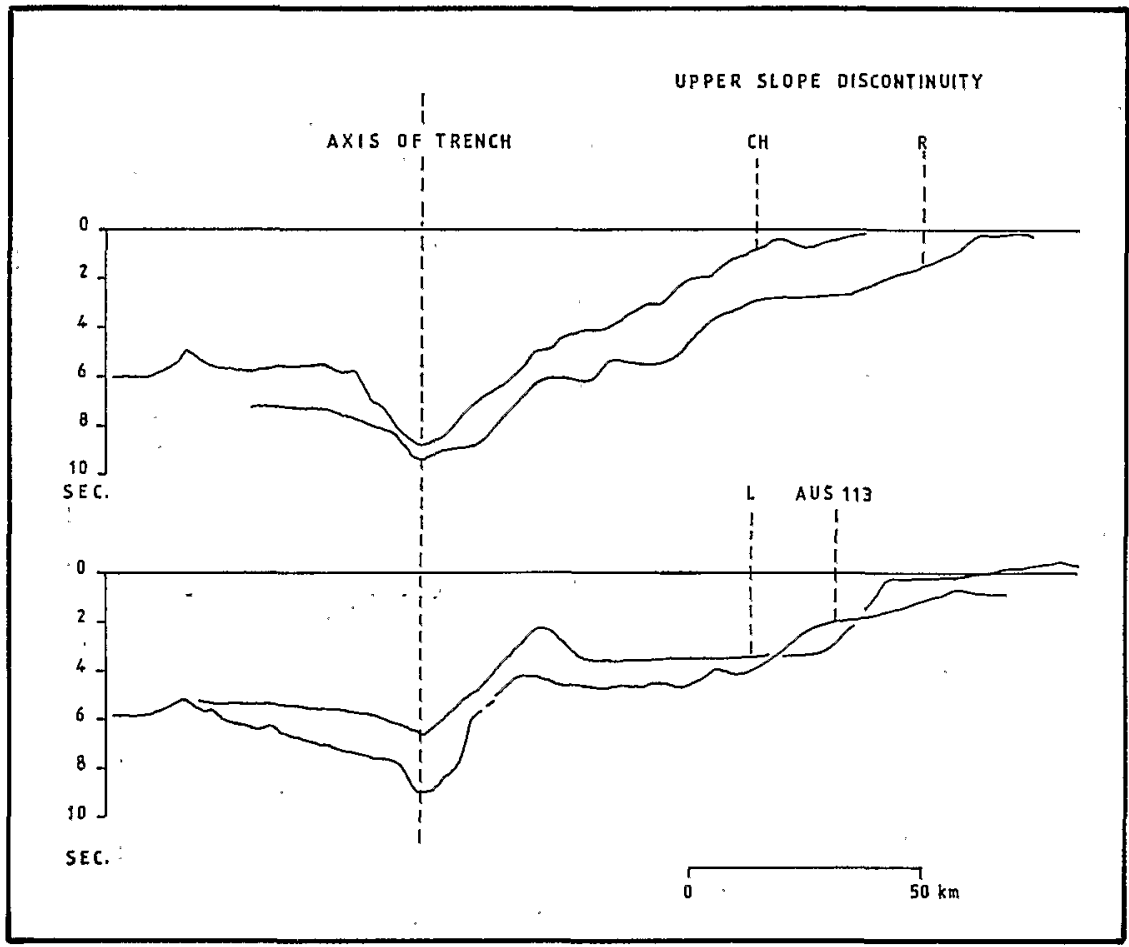

Fig. 7. Comparative bathymetric profiles across inner trench slopes of the New Hebrides [CH (Chain) and AUS (Austradec) 113], Ryukyu (R) and West Luzon (L) (from Karig and Sharman, 1975).

according to whether or not there is a neighbouring island to serve as a source of sedimentation.

Type Al: shown on profile AUS 113; the lower slope is steep and the upper slope is more subdued.

Type A2: shown on the CHAIN profile is a more developed form than the previous one: the upper slope has been modified by sediments from the island of Efate.

Group $B$. These are the slopes observed in the south: both flanks of the trench slope are gentle, and, as in the previous case, the upper slope may be modified by sediments from the arc.

Type B1: shown on profile EVA 201. The trench slope break between the lower and upper slopes is clearly defined.

Type B2: shown on profile EVA 317 . The slope is straightened out by sediments from the island of Erromango.

Therefore, a wide variety of inner slope forms can be seen to exist over roughly $220 \mathrm{~km}$. For reasons of comparison, it is also useful to note (Fig. 7) that on neighbouring profiles such as CHAIN and AUS 113, where the distance is less than $50 \mathrm{~km}$, the inner slopes are very similar to those observed on slightly older arcs with wider accretionary prisms which, according to KARIG and SHARMAN (1975), are characteristic of two different types of accretion. In our interpretation, within both morphological groups A and B, type 2 is derived from type 1 according to the extend of sedimentation from the arc. 


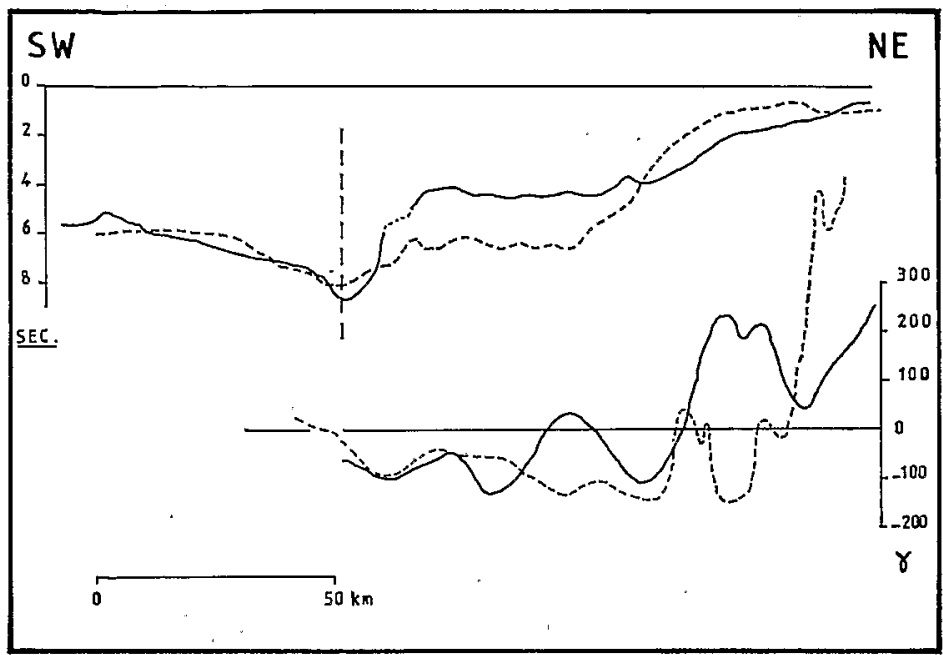

Fig. 8. Comparative magnetic anomalies and bathymetric profiles AUS 113 (solid lines) and EVA 201 (broken lines).

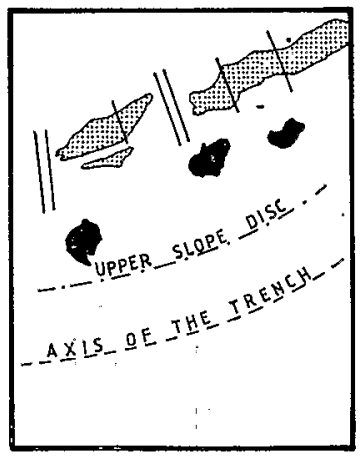

Fig. 9. Relative positions of the troughs at the rear of the New Hebrides island arc, the trench and the upper slope discontinuity. Double lines show major fractures.

According to our observations, there is a link between the inner and the outer flanks of the trench and therefore a tendency to symmetry. One is tempted to deduce that the form of the outer flank determines the inner flank. However, is this merely a question of morphology or, as observed by KARIG and Sharman (1975) is there a difference in the type of accreted material? Magnetic anomalies along AUS 113 and EVA 201 profiles (Fig. 8), morphologically very different, are not different enough to permit definite conclusions to be drawn concerning a change of the nature of accreted material.

\section{Morphology of the Troughs at the Rear of the Arc}

The troughs at the rear of the New Hebrides island arc, discovered during the Coriolis cruises (Puech and Reichenfeld, 1969) were described as "en echelon inter-arc basins" (KARIG and MAMMERICKX, 1972), or extensional fault troughs (LUYENDYK et al., 1974) and as tectonic troughs (Dubors et al., 1975, 1978). The latter authors presented a de- 
tailed study of the troughs for all the New Hebrides arc and conclude that their formation must be originated in the asthenosphere.

The bathymetric chart (Fig. 3) pinpoints the position of these troughs and one can particularly see (Fig. 9) that the northernmost trough is clearly discontinued at both ends, probably on major fractures. The fracture which shifts the trough at the island of Er-

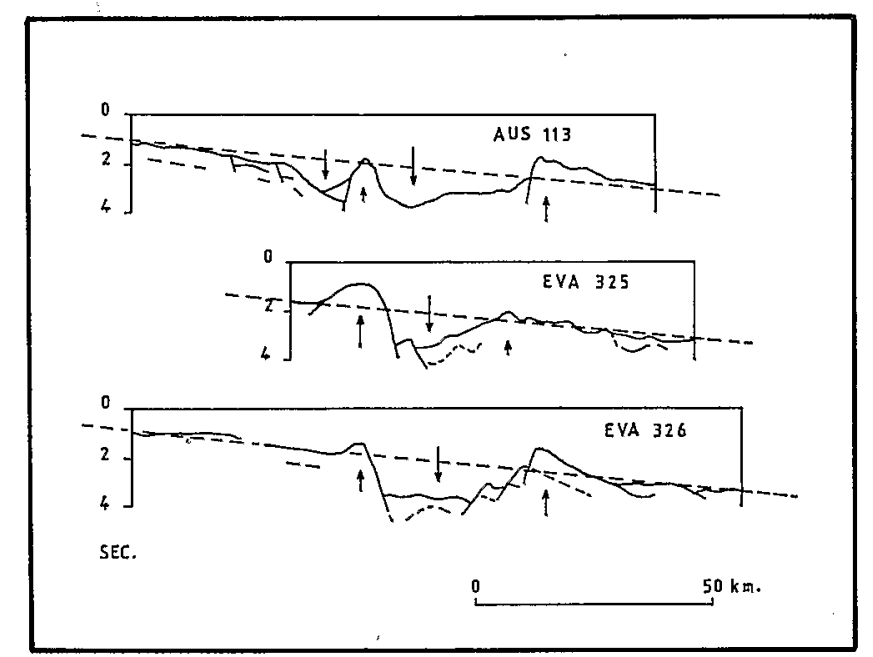

Fig. 10. Morphology of the troughs at the rear of the New Hebrides island arc. The intensity of vertical movement is proportional to the length of the arrows.

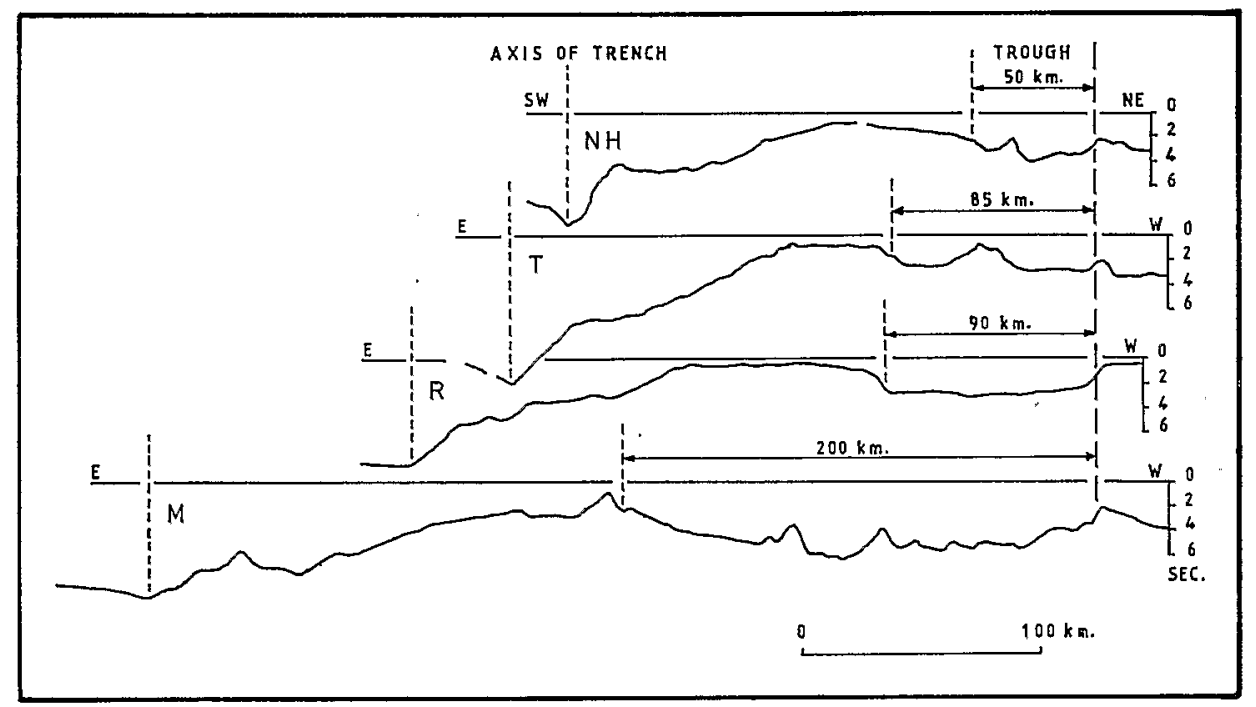

Fig. 11. Comparative widths and positions with respect to the trench axis of the trough at the rear of the New Hebrides island arc (NH) and similar structures on Tonga (T), Ryukyu (R), and Marianna (M) island arcs. 
romango is furthermore located in the extension of one of the irregularities observed on the dipping plate (on profile G.C. 30 at K 302, Figs. 3 and 4).

As observed by DuBors et al. $(1975,1978)$, the form of the troughs varies considerably, It is noted (Fig. 10) that the downthrow faults are, accordingly, roughly defined on one side or the other of the troughs. Despite these variations in the detailed configuration, the general form suggests (Fig. 10) a formation by vertical movements. The variations in the intensity of positive and negative vertical movements of horsts and grabens are sufficient to modify the form.

One can attempt to compare these troughs to equivalent structures on other arcs. Profiles of the Fig. 11 show morphologies which are comparable, without having necessarily the same origin. The troughs of Ryukyu and Mariana island arcs are inferred to have an origin similar to that of the troughs of the New Hebrides (DuBors et al., 1975, 1978) but to be at different stage of development. For the Tonga island arc it must be noted that the profile presented is not representative of the whole of the arc (J. DuponT, personnal communication).

\section{Conclusions}

The morphological study of the southern part of the New Hebrides island arc allowed us to pinpoint the various structural units and propose some assumptions which need to be substantiated by other methods.

1) There is an accretionary prism with a constant width of approximately $75 \mathrm{~km}$.

2) The morphology of this accretionary prism varies extremely rapidly along the arc and is controlled, firstly, by the morphology of the dipping plate and secondly by the existence of sources of sediments on the arc.

3) The arc and its connecting structural features, such as the troughs situated at its rear, show transversal discontinuities.

4) Major discontinuities of the arc could be related to those of the oceanic crust of the dipping plate.

\section{REFERENCES}

Carney, J.N. and A. MacFardane, Volcanotectonics events and pre-Pliocene crustal extension in the New Hebrides, in Geodynamics in South-West Pacific, pp. 91-104, Technip Ed., Paris, 1977.

Daniel, J., Phènomène de subduction et existence du prisme d'accrétion: enseignement de l'arc des Nouvelles-Hébrides, C.R. Acad. Sci. Paris, D, 286, 1755-1758, 1978.

Daniel, J., C. Jounannic, B. LaRue, and J. Recx, Interpretation of d'Entrecasteaux zone (North of New Caledonia), in Geodynamics in South-West Pacific, pp. 117-124, Technip Ed., Paris, 1977.

Drckinson, W.R., Widths of modern arc-trench gaps proportional to post-duration of igneous activity in associated magmatic arcs, J. Geophys. Res., 78, 3376-3389, 1973.

Dubors, J., F. Dugas, A. Lapouille, and R. Louat, Fossés d'effondrement en arrière de l'arc des Nouvelles Hébrides. Mécanismes proposés, Rev. Géo. Phys. Geol. Dyn., XVI. (1), 73-94, 1975.

Dubots, J., F. Dugas, A. Lapourlle, and R. Louat, The troughs at the rear of the New Hebrides island arc. Possible mechanisms, Can. J. Earth Sci., 15, 351-360, 1978.

Dugas, F., J. Dubots, A. Lapoulle, R. Louat, and C. Ravenne, Structural characteristics and tectonics of an active island arc: the New Hebrides, in Geodynamics in South-West Pacific, pp. 79-89, Technip Ed., Paris, 1977.

Johnson, T. and P. Molnar, Focal mechanisms and plate tectonics of the Southwest Pacific, J. Geophys. Res., $77,5000-5032,1972$.

Karig, D.E., Evolution of Arc Systems in the Western Pacific, Annu. Rev. Earth Planet. Sci., 2, 51-75, 1974.

Karig, D.E. and J. Mammerickx, Tectonic framework of the New Hebrides island arc, Mar. Geol., 12, 187205, 1972. 
Karig, D.E. and G.F. Sharmán, Subduction and accretion in trenches, Geol. Soc. Am. Bull., 86, 377-389, 1975.

LApouilte, A. Southern New Hebrides basin and western South Fiji basin as single marginal basin, Aus. Soc. Expl. Geophys. Bull., 9, 130-133, 1978,

Luyendyk, B.P., W.B. Bryan, and P.A. JezEK, Shallow structure of the New Hebrides arc, Geol. Soc. Am. Bull., 85, 1287-1300, 1974.

Mrtcheld, A.H.G. and A.J. WARden, Geological evolution of the New Hebrides island arc, J. Geol. Soc., 127, 501-529, 1971.

Puech, J.L. and C. Reichenfeld, Etudes bathymétriques dans la région des îles Erromango, Tanna et Anatom (Nouvelles Hébrides du Sud), C.R. Acad. Sci. Paris, 268, 1259-1261, 1969.

Ravenne, C., G. Pascal, J. Dubois, F. Dugas, and L. Montadert, Model of a young intra-oceanic arc: 'The New Hebrides Island arc, in Geodynamics in South-West Pacific, pp. 63-77, Technip Ed., Paris, 1977. 